\title{
Thermosensitive Block Copolymers Consisting of Poly( $N$-isopropylacrylamide) and Star Shape Oligo(ethylene oxide)
}

\author{
Seung Cheol Lee and Ji Young Chang \\ Department of Materials Science and Engineering, Seoul Kational Lniversity, Seoul 151-74t, Korea \\ E-mail: jichangôsnu.ackr \\ Received Harch 3, 2009, Accepted How 13, 2009
}

\begin{abstract}
Thennosensitive block copolymers of ethylene oxide and $N$-isopropylacrylamide (NPAM) were synthesized. A five amed star shape oligo(ethylene oxide) initiator with a cyclotriphosphazene core was prepared and used for the atom transfer radical polymerization (ATRP) of NIPAM. The lower critical solution temperatures (LCSTs) of the copolymers were 36 to $46{ }^{\circ} \mathrm{C}$, higher than that of PNIPAM ( $\left.32{ }^{\circ} \mathrm{C}\right)$, depending on their molecular weights. The copolymers were soluble in water below the LCSTs but formed micelles above the LCSTs. The thermosensitive micellization behaviors of the polymers were investigated by fluorescence spectroscopy. With increasing the temperature of an aqueous solution of $\mathbf{P} 2$ and pyrene above the LCST, the peak of $333 \mathrm{~nm}$ red-shifted to appear around $339 \mathrm{~nm}$ and its intensity increased significantly, indicating the micelle formation. The transfer of pyrene into the micelles was also confimed by a confocal laser scanning microscope. The fluorescence image obtained from P2 in an aqueous pyrene solution exhibited a green envission resulting from the pyrene transferred into the micelles. Salt effects on the solubility of the copolymers in an aqueous solution were investigated. The LCST of P2 decreased sharply as the concentration of sodium chloride increased, while decreased slowly with potassium chloride.
\end{abstract}

Key Words: Block copolymers. Thermosensitive poly'mers. Lower critical solution temperature. Cyclotriphosphazene

\section{Introduction}

Water soluble thermosensitive polymers that show a lower critical solution temperature (LCST) have widely been investigated due to their potential applications such as controlled drug delivery. ${ }^{3}$ biomimetic actuators. " chromatographic separations. ${ }^{3}$ gene-transfection agents. ${ }^{4}$ and immobilized biocatalysts. Below the LCST the polymer molecules exist in an aqueous solution as extended coils, surrounded by ordered water molecules. while above the LCST the polymer precipitates out of the solution. Block copolymers of water soluble thermo-responsive polymers having different hydrophilic blocks have also attracted considerable attention because of their unique self aggregation behaviors depending on a temperature as well as a concentration. These double hydrophilic block copolymers dissolve in water homogeneously below the LCSTs of the thermo-responsive blocks and behave like amphiphilic block copoly mers above the LCSTs. ${ }^{6}$

Poly (ethy lene oxide)-poly (N-isopropylacry lamide) (PEOPNIPAM) is one of the typical double hydrophilic block copolymers. PNIPAM is a well known thermosensitive polymer. which exhibits a rapid and reversible hydration-dehydration change in response to small temperature cycles around its LCST $\left(32^{\circ} \mathrm{C}\right)$. PEO shows excellent biocompatibility and water solubility. The thermally induced micellization of $\mathrm{PEG}$ $b$-PNIPAM has been studied by several groups. ${ }^{7 \cdot]+}$ Below the LCST of PNIPAM both blocks are hydrophilic and soluble in water. Above the LCST of PNIPAM, the copolymer becomes amphiphilic to form a micelle.

Another interesting property of PEO is its ability to capture metal cations. The complexation of PEO considers weaker and less selective than macrocyclic ethers such as crown ethers. ${ }^{15}$ but some chemically modified PEOs with structures mimicking natural acyclic polyethers showed fairly good complexation ability and selectivity. ${ }^{161 ?}$ Oligo(etlyylene oxide) or crown ether bearing polyphosphazenes were also used for cation complexation.

In this paper. we report thermoresponsive polymers consisting of oligo(ethylene oxide) and poly ( $\mathrm{N}$-isopropyl acrylanide) blocks. Cyclotriphosphazenes are versatile starting materials for the șinthesis of multifunctional cyclic compounds. ${ }^{21.2}$ We prepared a cyclotriphosphazene initiator having five oligo (ethylene oxide) substituents and used for the atom transfer radical polymerization (ATRP) of NIPAM. The resulting copolymers had a star shape oligo(ethy lene oxide) block with a polypodand structure, which were expected to capture metal cations.

\section{Experimental Section}

Materials and Instnuments. Hexachlorocyclotriphosphazene. 2-bromoisobutyryl bromide tris(2-aninoethyl)amine, and 4hydroxybenzaldehyde were purchased from Aldrich Chemical Co. and used as received. Tetrahydrofuran (THF) was dried over sodium metal and distilled. Di(ethylene oxide) monomethyl ether was purified by azeotropic distillation with benzene. $\gamma$-Isopropylacrylanide (NIPAM) was purified by recrystallization from $n$-hexane and dried carefully in a vacuum. Tris(2-dimethylaninoethyl)amine (Me TREN) was synthesized by following the method of Ciampolini. "Nuclear magnetic resonance (NMR) spectra were measured by a Bruker Avance DPX-300 (300 MHz for ${ }^{l} \mathrm{H}$ NMR) spectrometer and a 
Bruker Avance DPX-500 (200 MHz for ${ }^{31}$ P NMR) spectrometer. Elemental analyses were carried out on a Flash EA 1112 elemental analyzer. Fluorescence spectra were recorded on a RF-5301 spectrafluorophotometer (Shimadzu) with a $150 \mathrm{~W}$ xenon lamp and a $1 \mathrm{~cm}$ quartz cell. Gel permeation chromatographic (GPC) analy sis was conducted in THF at 35 ${ }^{\circ} \mathrm{C}$ with a M930 solvent delivery system and a RI750F refractive index detector from Younglin, equipped with Styragel HR 5 E and Sty ragel HR 6 columns from Waters. Approximate calibration of the column was accomplished by means of narrow molecular weight polystyrene standards. The cloud points of the copolymers were determined by turbidity measurement using a Sinco S-3150 UV-visible spectrophotometer. The cloud point was defined as the temperature at the inflection point in the absorbance of a polymer solution ( 0.2 wt \%), which was measured at $450 \mathrm{~nm}$ while the temperature was raised from 20 to $60^{\circ} \mathrm{C}$ at increment of $0.2{ }^{\circ} \mathrm{C} / \mathrm{min}$. Confocal laser scanning microscopy study was performed by a radiance 2000/MP (Bio-RAD), equipped with an IR laser as the light source.

Synthesis of Compound 2. A solution of diethylene oxide monomethylether ( $3.30 \mathrm{~g} .27 .5 \mathrm{mmol})$ in $100 \mathrm{~mL}$ of THF was added dropwise to a suspension of sodium hydride $(0.72 \mathrm{~g}$. $30.0 \mathrm{mmol})$ in THF $(50 \mathrm{~mL})$ at room temperature. To the solution was added a solution of hexachlorocyclotriphosphazene $(1.74 \mathrm{~g} .5 .0 \mathrm{mmol})$ in THF $(100 \mathrm{~mL})$ at room temperature and the mixture was stirred at reflux temperature for $48 \mathrm{~h}$. After filtration using celite and evaporation. the crude product was isolated by column chromatography on silica gel (chloroform $/$ methanol $=19 / 1 \mathrm{v} / \mathrm{v}$ ) and used for the next reaction without further purification.

A solution of 4-hydroxybenzaldehyde $(0.61 \mathrm{~g} .5 .0 \mathrm{mmol})$ in $50 \mathrm{~mL}$ of THF was added dropwise to a suspension of sodium hydride $(0.15 \mathrm{~g} .6 .0 \mathrm{mmol})$ in THF $(50 \mathrm{~mL})$ at room temperature. To the solution was added a solution of compound $\mathbf{1}$ $(1.7+$ g. $5.0 \mathrm{mmol})$ in THF $(100 \mathrm{~mL})$ at room temperature and the mixture was stirred at reflux temperature for $24 \mathrm{~h}$. After filtration using celite the solvent was evaporated and the compound 2 was isolated by column chromatography on silica gel (chloroform $/$ methanol $=24 / 1 \mathrm{v} / \mathrm{v})$. Yield: $1.96 \mathrm{~g}(+6 \%)$. ${ }^{1} \mathrm{H}$ NMR $\left(300 \mathrm{MHz}\right.$. DMSO- $d_{6}$ ) o 9.97 (s. -CHO) . 7.+0-7.95 (dd, Ar-H). 3.22-4.58 (m, $\left.\mathrm{CH}_{2}\right)$. ${ }^{31}$ P NMR (200 MHz. DMSO$\left.d_{6}\right)$ ô 17.8 (d. DEO-P-DEO). 14.5 (t. DEO- P-OAr). Anal. Calcd (in wt\%) for $\mathrm{C}_{33} \mathrm{H}_{6 ;}, \mathrm{N}_{3} \mathrm{O}_{1}: \mathrm{P}_{3}: \mathrm{C}, 45.12 ; \mathrm{H}, 7.10 ; \mathrm{N}, 4.93$. Found: C. 45.14 ; H. 7.21 ; N. 4.85 .

Synthesis of Compound 3. To a solution of compound 2 $(2.00 \mathrm{~g} .2 .4 \mathrm{mmol})$ in THF-methanol $(100 \mathrm{~mL} .1: 1$, v/v) was added sodium borohydride $(0.10 \mathrm{~g} .2 .5 \mathrm{mmol})$ at room temperature. After stiming for $2 t h$ at room temperature. distilled water was added dropwise until the precipitates were dissolved. The reaction mixture was concentrated by evaporation under reduced pressure. Compound 3 was isolated by column chromatography on silica gel (methylene chloride/ methanol $=19 / 1 \mathrm{v} / \mathrm{v})$. Yield: $1.88 \mathrm{~g}(92 \%) .{ }^{\mathrm{H}} \mathrm{H}-\mathrm{NMR}(300 \mathrm{MHz}$. DMSO- $\left.d_{b}\right) \dot{0} 6.95 .7 .79$ (dd. $+\mathrm{H} . \mathrm{Ar}-\mathrm{H}$ ). 5.20 (t. $\left.1 \mathrm{H} . \mathrm{OH}\right) .4 .50$ (d, $\left.2 \mathrm{H}_{2} \mathrm{CH}_{2}\right), 3.31-4.02\left(\mathrm{~m}_{1} \mathrm{CH}_{2}\right.$ in dietlylene oxide) ${ }^{31} \mathrm{P}-\mathrm{NMR}$ $\left(200 \mathrm{MHz}, \mathrm{DMSO}-d_{6}\right)$ o 14.5 (t, DEO-P-OAr), 17.8 (d. DEO$\mathrm{P}-\mathrm{DEO}$ ). Anal. Calcd (in wt\%) for $\mathrm{C}_{3:} \mathrm{H}_{62} \mathrm{~N}_{3} \mathrm{O}_{1}: \mathrm{P}_{3}: \mathrm{C} .45 .02$ :
H. 7.32; N. 4.92. Found: C, $45.05 ;$ H. $7.31 ;$ N. 4.83.

Synthesis of Star Shape Oligo(ethylene oxide) Initiaor (4). To a solution of compound $3(1.00 \mathrm{~g} .1 .2 \mathrm{mmol})$ in THF (50 $\mathrm{mL}$ ) were added triethylamine ( 0.24 g. $2.3 \mathrm{nunol})$ and 2 -bromoisobuty lbromide $(0.27 \mathrm{~g} .1 .2 \mathrm{mmol})$. After stirring for $6 \mathrm{~h}$ at room temperature, the solvent was evaporated and the product was isolated by column chromatography on silica gel (chloroform $/$ methanol $=19 / 1 \mathrm{v} / \mathrm{v})$. Yield: $1.14 \mathrm{~g}(95 \%) .{ }^{1} \mathrm{H}-\mathrm{NMR}$ $\left(300 \mathrm{MHz} . \mathrm{DMSO}-d_{6}\right) \hat{o} 7.30 .7 .16$ (dd. $\left.4 \mathrm{H}, \mathrm{ArH}\right) .5 .15$ (s, $2 \mathrm{H}$. $\left.\mathrm{CH}_{2}\right), 3.31-4.02\left(\mathrm{~m}, 40 \mathrm{H}, \mathrm{CH}_{2}\right.$ in ethyleneglycol protons). $3.18\left(\mathrm{~s}, 15 \mathrm{H} . \mathrm{CH}_{3}\right.$ of diethyleneglycol), 1.90 (s. $\left.6 \mathrm{H} .\left(\mathrm{CH}_{3}\right)_{2}\right)$. ${ }^{31} \mathrm{P}-\mathrm{NMR}\left(200 \mathrm{MHz}, \mathrm{DMSO}-d_{6}\right)$ o 14.5 (t. DEO-P-OAr), 17.8 (d. DEO-P-DEO). Anal Calcd (in wt \%) for $\mathrm{C}_{36} \mathrm{H}_{6}: \mathrm{BrN}_{3} \mathrm{O}_{1} 8 \mathrm{P}_{3}$ : C. 43.12: H. 6.73: N. 4.19. Found: C. 42.95: H. 6.62: N. 4.06.

Preparation of LinearPEG Initiator(5). Triethylamine $(0.6$ g. $6 \mathrm{mmol}$ ) was added to a solution of polyethylene oxide metyl ether $\left(\mathrm{M}_{\mathrm{n}}=750\right)(1.5 \mathrm{~g} .2 \mathrm{mmol})$ in methy lene chloride $(50 \mathrm{~mL})$. After stirring for $2 \mathrm{~h}$ at room temperature, 2 bromoisobuty ryl bromide ( $0.50 \mathrm{~g} .2 .2 \mathrm{mmol}$ ) was added. The reaction nixture was stirred for $6 \mathrm{~h}$ at roon temperature. After filtration, the filtrate was concentrated by evaporation under reduced pressure. The product was isolated by column chromatography on silica gel $\left(\mathrm{CH}_{2} \mathrm{Cl}_{3} \mathrm{MeOH}=24 / 1 \mathrm{v} / \mathrm{v}\right)$ as an oil. Yield: $1.17 \mathrm{~g}(65 \%)$. ${ }^{\mathrm{H}} \mathrm{H}-\mathrm{NMR}\left(300 \mathrm{MHz}\right.$. DMSO- $\left.d_{6}\right) \delta \dot{\delta}+.3(\mathrm{t}$. $\left.2 \mathrm{H}, \mathrm{CH}_{2}\right) .3 .5\left(\mathrm{~m}, \mathrm{CH}_{2}\right.$ in ethylene oxide protons) $1.9(\mathrm{~s} .6 \mathrm{H}$, $\left.\left(\mathrm{CH}_{3}\right)_{2}\right)$.

Synthesis of starEO- $b$-PNIPAM and PEG- $b$-PNIPAM. Initiator $+(0.10 \mathrm{~g} .0 .1 \mathrm{mmol})$ and $\mathrm{N}$-isopropylacrylanide $(0.57 \mathrm{~g} .5 .0 \mathrm{mmol})$ were dissolved in $3 \mathrm{~mL}$ of water/DMF $(2 / 1$. v/v) in an anpule $(10 \mathrm{~mL})$. A solution of Me $\operatorname{TREN}(0.023 \mathrm{~g}$. $0.1 \mathrm{mmol})$ and $\mathrm{CuBr}(0.014 \mathrm{~g} .0 .1 \mathrm{mmol})$ in $1 \mathrm{~mL}$ of DMF was added to the initiator/monomer solution. The mixture in the anpule was degassed five times with a freeze-pump-thaw procedure. The ampule was sealed in vacuo and poly'merized at $30^{\circ} \mathrm{C}$. After 5 h. the ampule was opened, and the solution was passed through a neutral aluminum oxide column to remove the catalyst. The filtrate was concentrated under reduced pressure and the resulting polymer was isolated by dialysis in water through a cellulose membrane tube with molecular weight cutoff of 2000 . The block copolymer was freeze-dried. ${ }^{1} \mathrm{H}-\mathrm{NMR}\left(300 \mathrm{MHz}\right.$. DMSO- $\left.\alpha_{6}\right) \hat{\delta} 7.20$ (br. NH and aromatic). 4.95 (s. $\mathrm{CH}_{2}$ in starEO). 3.90 (br. $\mathrm{CH}$ in PNIPAM). $3.10-3.60$ (m. $\mathrm{CH}_{2}$ in DEO of starEO). 1.95 (br. $\mathrm{CH}_{2}$ in PNIPAM), 1.45 (br. $\mathrm{CH}_{2}$ in PNIPAM), 1.05 (Br. $\mathrm{CH}_{3}$ in PNIPAM) ${ }^{3.1}$ P-NMR (200 MHz. DMSO- $d_{b}$ ) o 14.5 (t. DEOP-OAr). 17.8 (d. DEO-P-DEO).

Linear PEG- $b$-PNIPAM was also prepared in the same manner except that PEG initiator 5 was used instead of $4 .{ }^{~} \mathrm{H}$ NMR $\left(300 \mathrm{MHz}\right.$. DMSO- $d_{b}$ ) $\hat{o} 7.20$ (br. NH in PNIPAM), 3.90 (br. $\mathrm{CH}$ in PNIPAM). 3.50 (br. $\mathrm{CH}_{2}$ in PEG). 1.95 (br. $\mathrm{CH}_{2}$ in PNIPAM). 1.45 (br. $\mathrm{CH}_{2}$ in PNIPAM), $1.05\left(\mathrm{Br}^{-\mathrm{CH}_{3}}\right.$ in PNIPAM).

\section{Results and Discussion}

Synthesis. A five armed star shape oligo(ethylene oxide) (starEO) initiator with a cyclotriphosphazene core for the ATRP of NIPAM was synthesized according to Scheme 1 . 


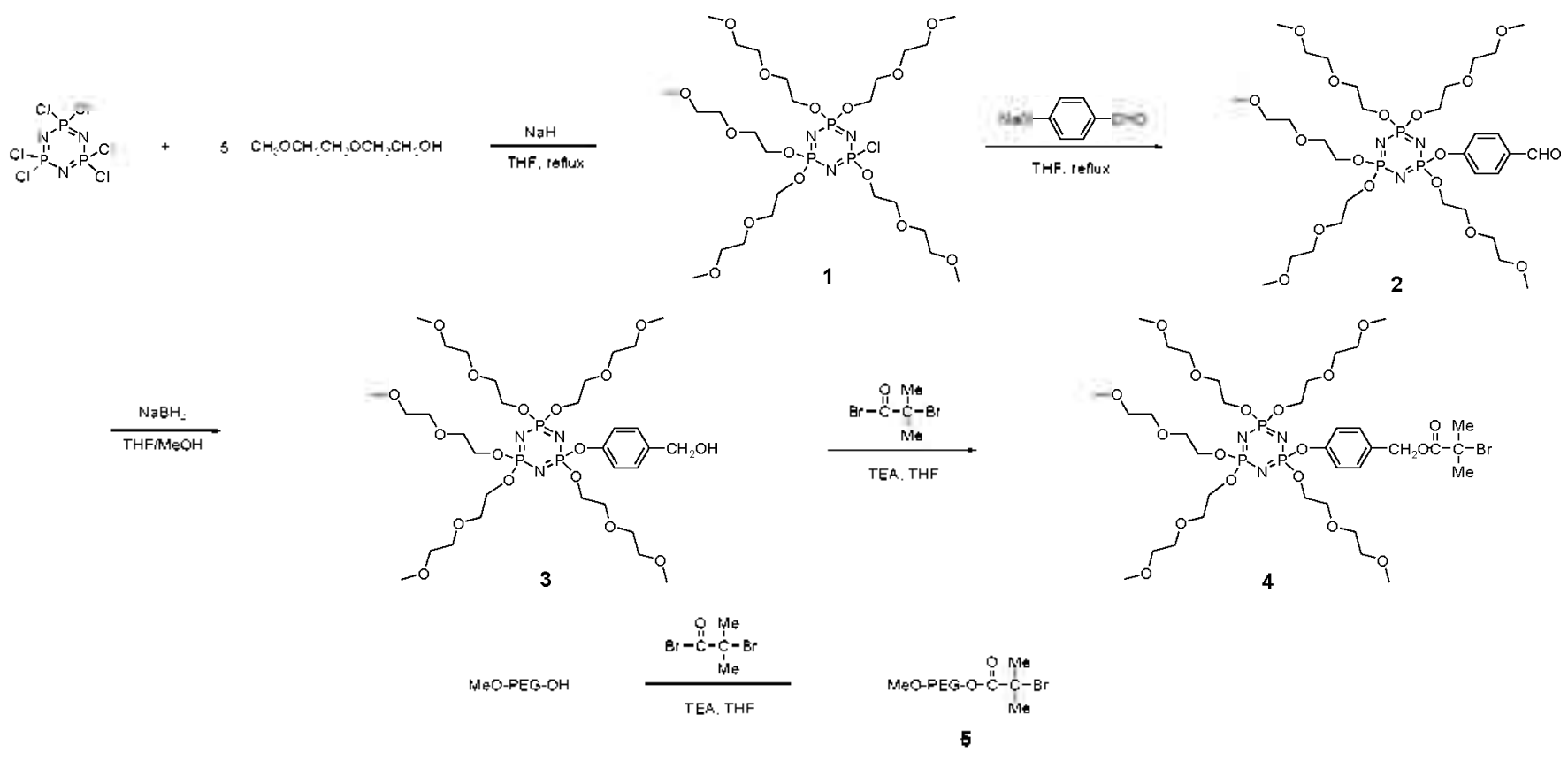

Scheme 1

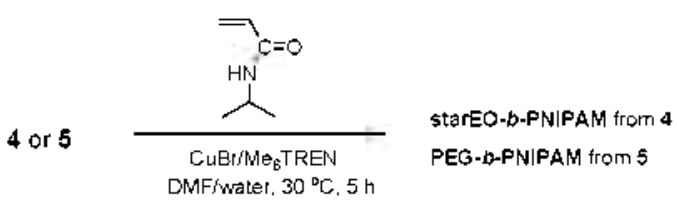

Scheme 2

Table 1. Molecular Weights and LCSTs of the Copolvmers.

\begin{tabular}{ccccc}
\hline Copolymer & Initiator & $\mathrm{M}_{10}{ }^{\sigma}$ & $\mathrm{M}_{w}{ }^{\sigma}$ & $\begin{array}{c}\mathrm{LCST} \\
\left({ }^{\circ} \mathrm{C}\right)\end{array}$ \\
\hline starEO-b-NIPAM (P1) & 4 & 5100 & 5300 & 46 \\
starEO-b-NIPAM (P2) & 4 & 6100 & 6700 & 38 \\
starEO-b-NIPAM (P3) & $\mathbf{4}$ & 7300 & 7900 & 36 \\
PEG-b-PNIPAM & $\mathbf{5}$ & 7100 & 7800 & 39 \\
\hline
\end{tabular}

"Measured by GPC in THF with polystyrene standards. "Mn of a PEG block $=750$

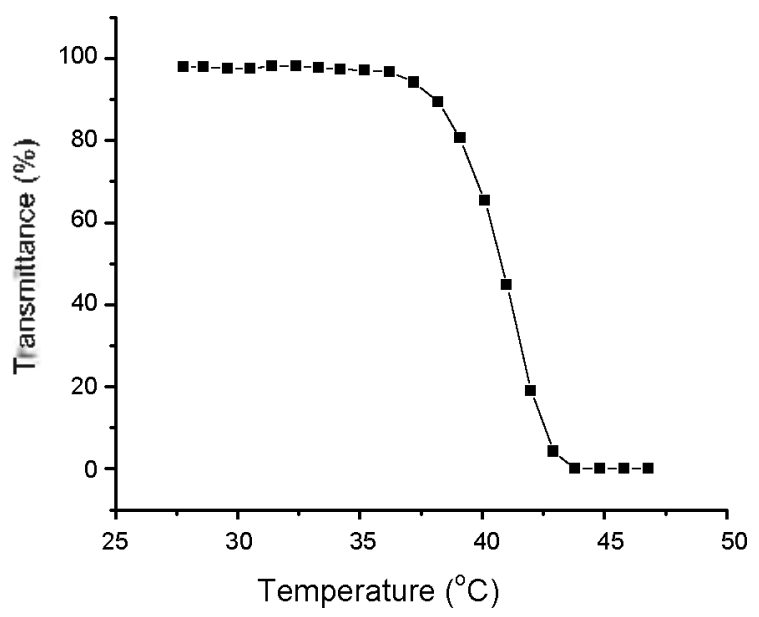

Figure 1. Transmittance vs temperature of $\mathbf{P 2}$ in an aqueous solution.
Five clloro groups of hexachlorocyclotriphosphazene were first substituted by sodium salt of methoxyethoxyethoxide. The remaining chloro group was replaced by sodium salt of 4fornylphenoxide. After converting the fornyl group into an alcohol with sodium hydride. the resulting compound was reacted with 2-bromoisobutyryl bronide to give macroinitiator 4. Linear PEO initiator 5 was also prepared by reaction of poly'(ethy'lene oxide) methyl ether (MeO-PEO-OH) $\left(\mathrm{M}_{\mathrm{n}}=750\right.$ ) with 2-bromoisobutyryl bromide.

The structure of compound 4 was confirmed by ${ }^{1} \mathrm{H}$ NMR and ${ }^{21} \mathrm{P}$ NMR spectroscopy. In the ${ }^{1} \mathrm{H}$ NMR spectrum in DMSO- $d_{6 .}$ two doublet peaks for aromatic ring protons appeared at 7.12 and $7.35 \mathrm{ppm}$ and a singlet peak for isobutyrylbronide group protons at $1.95 \mathrm{ppm}$. The ${ }^{31} \mathrm{P} N \mathrm{NR}$ spectrum showed a doublet peak at $17.8 \mathrm{ppm}$ for phosphorous atons substituted with two methoxyethoxyethoxy groups and a triplet peak at $14.5 \mathrm{ppm}$ for a phosphorous atom substituted with a methosyethoxyethoxy and a phenosy group.

$N$-Isopropylacrylamide was polymerized in DMF/water ( $1 / 1 \mathrm{v} / \mathrm{v}$ ) by ATRP using initiator 4 or 5 and $\mathrm{CuBr} / \mathrm{Me}_{6} \mathrm{TREN}$ as a catalyst/ligand system (Scheme 2). The polymerization results are summarized in Table 1.

The LCSTs of the polymers were measured using a UV. visible spectrophotometer. The cloud point was defined as the temperature at the inflection point in the absorbance of a polymer solution $(0.2 \mathrm{wt} \%)$ at $450 \mathrm{~nm}$ on heating (Figure 1 ). The LCSTs of the copolymers were higher than that of PNIPAM $\left(32^{\circ} \mathrm{C}\right)$ possibly due to the hydrophilic PEG end group. They were also dependent on their molecular weights. When the length of a PNIPMA block increased. the LCST of the polymer decreased (Table 1$)^{24}$

The thennosensitive micellization behaviors of the polymers were investigated. Figure 2(a) shows the fluorescence excitation spectra of pyrene molecules in the polymer solution. which were obtained below and above the LCST. The 
(a)

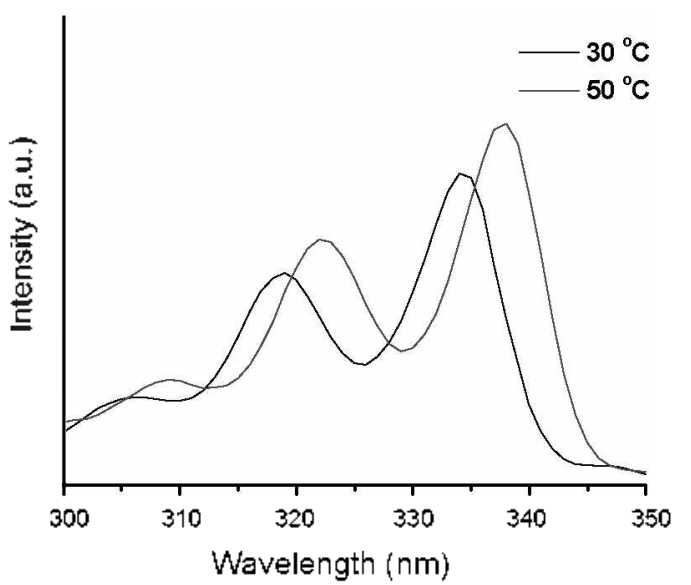

(b)

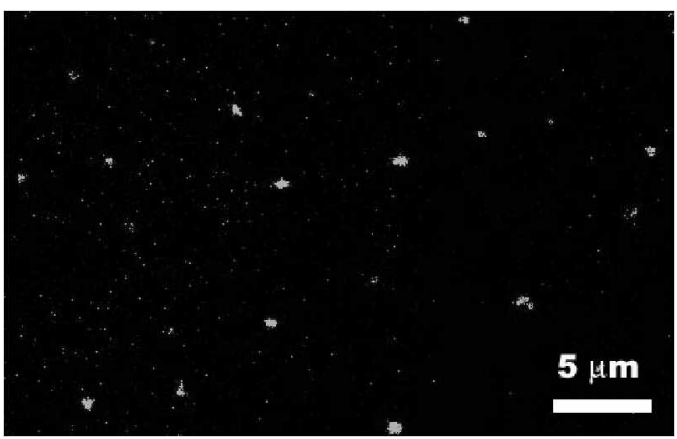

Figure 2. (a) Fluorescence excitation spectra $\left(\lambda_{\text {em }}=393\right.$ mni) of a solution of pyrene and P2 in water, measured at 30 and $500^{\circ} \mathrm{C}$. (b) CLSM fluorescence image of pyrene-loaded micelles.

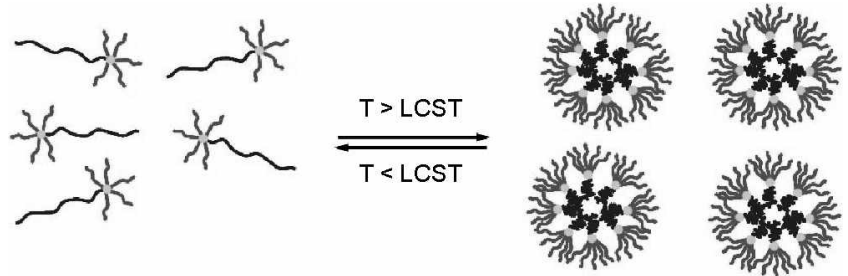

Figure 3. The thermosensitive micellization of starOE- $b$-PNIPAM

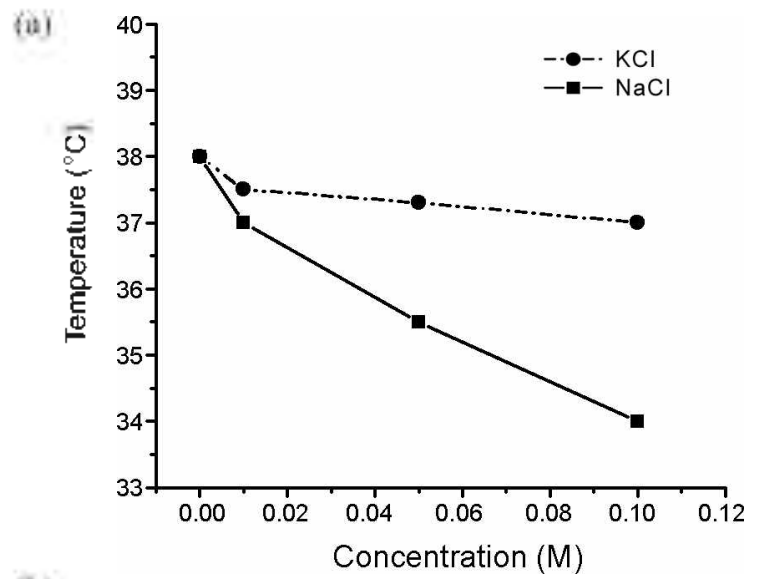

(b)

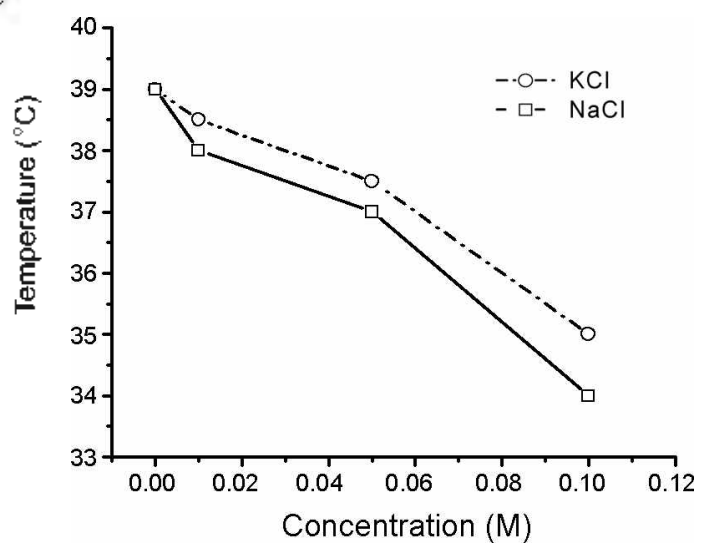

Figure 4. LCST changes of (a) starEO- $b$-PNIPAM (P2) and (b) linear PEG-b-PNIPAM according to concentrations of $\mathrm{NaCl}$ and $\mathrm{KCl}$. sample solution was prepared as follows. A solution of pyrene $(0.012 \mathrm{mg})$ in THF $(0.12 \mathrm{~mL})$ was added to distilled water $(100 \mathrm{~mL}$ ) and vigorously stirred for $30 \mathrm{~min}$ to evaporate THF. resulting in an aqueous pyrene solution $\left(1.2 \times 10^{-6} \mathrm{M}\right)$. The py rene solution was mixed with an aqueous solution of P2 (2 $\mathrm{ng} / \mathrm{nL}$ ) in the same anounts. With increasing the temperature above the LCST. the peak of $333 \mathrm{~nm}$ red-shifted to appear around $339 \mathrm{~nm}$ and its intensity increased significantly, indicating the micelle formation. Below the LCST of P2. pyrene molecules and the copolymer made a homogeneous solution. Above LCST, the PNIPAM block became hydrophobic. while the oligo(ethỵlene oxide) block remained hy'drophilic. As a result. the copolymer formed a nucelle so that py rene molecules transferred into the hydrophobic interior (Figure 3). The transfer of py rene into the starEO- $b$-PNIPAM nicelles was also confirmed by a confocal laser scanning nicroscope (CLSM). The fluorescence image obtained from starEO- $b$-PNIPAM $(20 \mathrm{mg})$ in an aqueous py rene solution $(6 \times$ $10^{-*} \mathrm{M} .10 \mathrm{~mL}$ ) exhibited a green emission resulting from the py rene transferred into the micelles (Figure $2 b$ ).

It has been well known for many years that the solubility of certain proteins in water decreases in the presence of a salt. Sinular salt effects on the solubility of PNIPAM in an aqueous solution have been also reported. The LCST of PNIPAM was found to decrease continuously as the concentration of a salt increased. It is generally believed that the salt ions interact with water molecules surrounding PNIPAM, leading to destabilize the hydrogen bondings between the polymer and water $^{25-2:}$ As a result. the PNIPAM-PNIPAM interactions become stronger than the water-PNIPAM interactions and the polymer molecules precipitate. We investigated the effects of sodium chloride and potassium chloride on the LCST and micelle formation of starEO- $b$-NIPAM. Aqueous solutions of $\mathbf{P} 2$ containing various amounts of the salts were prepared and their cloud point temperatures were measured. The LCST of P2 decreased sharply as the concentration of sodium chloride increased, while decreased slowly with potassium chloride (Figure 4). For comparison we also prepared linear PEG- $b$ PNIPAM $\left(\mathrm{M}_{11}=7100 . \mathrm{PDI}=1.08\right)$ using linear macroinitiator 5 obtained from $P E G$ with $M_{13}$ of 750 . In contrast to $\mathbf{P 2}$. the 
linear block copolymer showed a continuous decrease in the LCST according to the concentrations of both sodium and potassium cluoride salts.

P2 has a cyclotriphosphazene head with five methoxyethoxyethoxy groups. This cyclotriphosphazene polypodand is known to have better complex forming capability and selectivity for metal cations than linear PEG. ${ }^{28}$ We presume that methoxyethoxyethoxy group substituted cyclotriphosphazene polypodand would interact with potassium ions more strongly and disturb their interaction with PNIPAM

In summary. we prepared thermosensitive double hydrophilic block copolymers (starEO- $b$-NIPAM) by ATRP of NIPAM using a five oligo(ethylene oxide) substituted cyclotriphosphazene as an initiator. They were soluble in water below the LCSTs and became amphiphilic to form micelles above the LCSTs. The water solubility of the polymers decreased in the presence of a salt and the effect of potassium chloride on the LCST was less pronounced compared with sodium clloride.

Acksowledgments. This work was supported by the Korea Science and Engineering Foundation (R01-2007-000-103240)

\section{References}

1. Qui, Y.; Park, K. Adv. Drwg Delwert Rev, 2001, 53,312

2. Chvtry, V.; Ulbrich, K. J. Bioact. Compat. Polm 2001, 16, 427.

3. Ty degaard-Axelsen, A. M.; Hoiby, P. E:; Holnistrom, K.: Russell, N.; Knochel, S. Appl. Emiron. Aficrob. 2004, 70,4111.

4. Zintchenco, A.: Ogris, M.: Wagner, E. Bioconingate Chem. 2006. 17,766

5. Bergbreiter, D. E.: Case, B. L.; Liu. Y. S.; Caraway, T. W. Macromolectiles 1998, 31, 6053

6. Yoshida, R.: Uchida, K.: Kaneko, Y.: Sakai, K.: Kikuchi, A.:
Sakurai, Y.: Okano, T. Nature 1995, 374, 240

7. Liang, D;: Zhou, S.: Song, L.; Zaitsev, V. S.: Chu, B. Macromolecules $1999,32,6326$

8. Virtanen, J.; Tenhu, H. Macromolecules $\mathbf{2 0 0 0}, 33,5970$.

9. Zhu, P. W: Napper, D. H. Langmitir $2000,16,8543$.

10. Virtanen, J.: Holappa, S.; Lemmetyinen, H.: Thenhu, H. M Aacromolecules 2002, 35.4763

11. Neradovic, D.; Soga, O.; Nostrum, C. F. V.; Hennirk, W. E. Biontaterials 2004, 25, 2409

12. Zhang, W.: Shi, L.; Wu, K.: An, Y. Macromolecules 2005, $38,5743$.

13. Kim, K. H.; Kim, I.: J०, W. H. Polmer 2005, \$6. 2836

14. Mitokawa, R.; Morishita, K.; Koizumi, S.; Nakahira, T.; Annaka, M. Hacrontolecules $2005,38,5748$

15. Choi, M. G.: Kim. H. I. Chang, S.-K. Bull. Korean Chem. Soc. 2008. 29. 567

16. Kim, H. J.; Kim, S. H.: Quang. D. T.; Kim, T. H.: Suh, I.-H.; Kim, J. S. Bull. Koneon Chem. Soc. 2007, 28,811

17. Okada. T. Anatyst 1993, $118,959$.

18. Blonsky. P. M.: Shriver. D. F.: Austin. P. E.: Allcock. H. R. J. Am. Chem. Soc. 1984, 106.6854

19. Blonsky, P. M.; Shriver, D. F.; Austin, P. E.; Allcock, H. R. Solid State Ionicy 1986, 1819, 258

20. Allcock, H. R.: Olmeijer, D. L.: O Connor, S. T. M. Macromolecules 1998. 31.753

21. Jun1, Y. . .; Mirl, J. H.; Ji, D. E.; Yoo, J. H.; Solu1, Y. S. Bull. Korem Chen. Soc. 2008, 29, 2323.

22. Shin, Y. T.; Park, C. S.; Lee, C. I.; Shin, J. S. Bull Korean Chem. Soc. 2008, 29, 2005

23. Ciampolini, M.; Nardi, N. Inorg. Chem. 1966, 5,41.

24. Furvk, S.; Zhang, Y.; Ortiz-Acosta, D.; Cremer, P. S.; Bregbreiter, D. E. J. Polm. Sci. Polm. Chem. 2006, Ht, 1492.

25. Inomata. H.: Goto. S.: Otake. K.: Saito, S. Langmin 1992.8.687.

26. Suwa, K.: Yamamoto, K.: Akashi, M.; Takano, K.: Tanaka, N.; Kunugi, S. Colloid Polmt. Sci. 1998, 276, 529-533.

27. Zhang, Y; Furyk, S.; Bergbreiter, D. E.; Cremer, P. S. J. Am. Chem. Soc. 2005, 127, 14505

28. Landini, D.; Maia, A.: Corda, L.; Maccioni, A.; Podda, G. Tetratedron Lett. 1989, 42.5781.

29. Gobbi, A.; Landini, D.; Maia, A.; Delogu, G.; Podda, G. J. Org. Chem. $1994,59,5059$ 